Jurnal Health Sains: p-ISSN: 2723-4339 e-ISSN: 2548-1398

Vol. 3, No. 1, Januari 2022

\title{
PENGETAHUAN SIKAP DAN PERILAKU ANAK REMAJA USIA 15-18 TAHUN TERHADAP PENGGUNAAN SUNSCREEN DI SMK KESEHATAN YANNAS HUSADA BANGKALAN
}

\author{
Safinatul Hujjah, Selma Siahaan \\ Fakultas Farmasi Universitas 17 Agustus 1945 Jakarta, Indonesia \\ Puslitbang Humaniora dan Manajemen Kesehatan Balitbangkes, Indonesia \\ Email: safinatul.hujjah@yahoo.com, almetaselma@gmail.com
}

\begin{tabular}{ll}
\hline INFO ARTIKEL & ABSTRAK \\
\hline Diterima & Sinar UV dapat memberikan dampak buruk bagi kulit manusia apabila \\
5 Januari 2022 & terpapar terlalu lama (BPOM, 2009). Minimnya pengetahuan dan \\
Direvisi & rendahnya tingkat penggunaan sunscreen pada remaja sehingga \\
15 Januari 2022 & dibutuhkan edukasi yang lebih baik dan lebih maksimal. Oleh karena itu, \\
Disetujui & untuk mendapatkan gambaran mengenai hal tersebut dibutuhkan \\
25 Januari 2022 & penelitian tentang Pengetahuan Sikap Dan Perilaku Anak Remaja Usia \\
\hline Kata Kunci: & 15-18 Tahun Terhadap Penggunaan Sunscreen Di SMK Kesehatan \\
sunscreen; & Yannas Husada di daerah Bangkalan. Pengumpulan data dilakukan \\
pengetahuan; sikap; & dengan menyebarkan kuesioner kepada responden sejumlah 63 orang. \\
perilaku & Data yang diperoleh kemudian dilakukan analisis univariat \\
& menggunakan perangkat lunak IBM SPSS dan uji chi square. Hasil \\
& analisis univariat menunjukkan sebanyak (4,8\%) responden memiliki \\
& tingkat pengetahuan yang baik, (47,6\%) memiliki pengetahuan yang \\
& cukup baik dan (47,6\%) memiliki pengetahuan yang kurang baik \\
& terhadap penggunaan sunscreen. Kemudian sebanyak (3,17\%) responden \\
& memiliki sikap yang baik, (50,79\%) memiliki sikap yang cukup baik dan \\
& (46,03\%) memiliki sikap yang kurang baik terhadap penggunaan \\
& sunscreen. Lalu (0\%) responden memiliki perilaku yang baik, (30,2\%) \\
& memiliki perilaku yang cukup baik dan (69,8\%) memiliki perilaku yang \\
& kurang baik terhadap penggunaan sunscreen. Uji chi square \\
& menunjukkan seluruh variabel memiliki nilai lebih dari 0,05 sehingga \\
& tidak ada hubungan diantara hal tersebut. Anak remaja atau siswa-siswi \\
& SMK Kesehatan Yannas Husada memiliki tingkat pengetahuan, sikap \\
dan perilaku yang cukup baik terhadap penggunaan sunscreen.
\end{tabular}

\section{ABSTRACT}

$U V$ rays can have a negative impact on human skin if exposed for too long (BPOM, 2009). The lack of knowledge and the low level of use of sunscreen in adolescents so that better and more optimal education is needed. Therefore, to get an overview of this, research is needed on Knowledge of Attitudes and Behaviors of Adolescents Aged 15-18 Years Against the Use of Sunscreen at the Yannas Husada Health Vocational School in the Bangkalan area. Data was collected by distributing questionnaires to 63 respondents. The data obtained were then performed with univariate analysis using IBM SPSS software and chi square test. The results of the univariate analysis showed that as many as (4.8\%) of respondents had a good level of knowledge, (47.6\%) had a fairly good knowledge and (47.6\%) had a poor knowledge of the use of

$\begin{array}{ll}\text { How to cite: } & \text { Hujjah. S. \& Siahaan (2022) Pengetahuan Sikap dan Perilaku Anak Remaja Usia 15-18 Tahun } \\ & \text { terhadap Penggunaan Sunscreen di SMK Kesehatan Yannas Husada Bangkalan. Jurnal Health Sains } \\ & 3(1) . \text { https://doi.org/10.46799/jhs.v3i1.404 } \\ & 2723-6927 \\ \text { E-ISSN: } & \text { Ridwan Institute }\end{array}$


sunscreen. Then as many as (3.17\%) respondents have a good attitude, (50.79\%) have a fairly good attitude and $(46.03 \%)$ have a bad attitude towards the use of sunscreen. Then (0\%) respondents have good behavior, (30.2\%) have quite good behavior and (69.8\%) have bad Keywords: $\quad$ behavior towards the use of sunscreen. The chi square test shows that all sunscreen; variables have a value of more than 0.05 so there is no relationship knowledge; attitude; between them. Teenagers or students of Yannas Husada Health behavior Vocational School have a fairly good level of knowledge, attitude and behavior towards the use of sunscreen

\section{Pendahuluan}

Sinar matahari memiliki panjang gelombang 10-400 $\mathrm{nm}$ yang disebut dengan sinar ultraviolet (UV) (Isfardiyana, 2014). Sinar UV terbagi menjadi sinar UVA, UVB, dan UVC (Setiati, 2008). Sinar UV bermanfaat untuk manusia, salah satunya untuk mensintesis vitamin dan juga berfungsi untuk membunuh bakteri. Namun, sinar UV juga dapat memberikan dampak buruk bagi kulit manusia apabila terpapar terlalu lama (BPOM, 2009).

Radiasi sinar UV pada kulit dapat memberikan efek akut dan kronik pada kulit. Efek akut yaitu terjadinya sunburn, respon pigmentasi (melanogenesis/ tanning), immunosupresi serta kerusakan jaringan konektif dermis (Yaar, 1995). Menurut (Tahir \& Jumina, 2002), pigmentasi, eritema dan fotosensitivitas merupakan perubahanperubahan jangka pendek atau perubahan akut yang dapat terjadi akibat paparan sinar UV matahari. Paparan radiasi UV sinar matahari terhadap kulit secara terus-menerus dapat menyebabkan efek kronis hingga kulit mengalami perubahan struktur dan komposisi (Droge, 2002; Kockler et al., 2012). Efek kronis atau efek jangka panjang yang dapat terjadi seperti penuaan dini dan keganasan atau meningkatnya resiko kanker kulit seperti melanoma (Tahir \& Jumina, 2002).

Indonesia merupakan negara dengan paparan sinar matahari yang cukup lama sehingga penggunaan tabir surya sangat dianjurkan (Tranggono \& Latifah, 2007) untuk mengurangi efek buruk dari paparan sinar matahari. Sunscreen termasuk ke dalam jenis tabir surya kimia atau tabir surya organik. Tabir surya kimia melindungi kulit dengan cara menyerap sinar matahari atau sinar UV dan mengubahnya menjadi energi panas (Hari et al., 2013; Lewies et al., 2014)

Hasil riset yang telah dilakukan sebelumnya menunjukkan kalangan remaja usia 15-20 tahun yang sedang dalam masa pubertas kurang peduli terhadap kesehatan kulitnya, terutama pada kulit wajah. Oleh karena itu, untuk mendapatkan gambaran mengenai hal tersebut dibutuhkan penelitian tentang Pengetahuan Sikap Dan Perilaku Anak Remaja Usia 15-18 Tahun Terhadap Penggunaan Sunscreen Di Smk Kesehatan Yannas Husada di daerah Bangkalan agar dapat digunakan sebagai bukti ilmiah terhadap pentingnya penggunaan sunscreen pada remaja.

\section{Metode Penelitian}

Jenis penelitian yang digunakan pada penelitian ini adalah metode penelitian deskriptif dalam bentuk survei dengan pendekatan kuantitatif menggunakan kuisioner. Desain penelitian menggunakan desain penelitian potong lintang atau cross sectional. Analisis data menggunakan analisis univariat.

Pengambilan data dilakukan dengan menyebarkan kuesioner. Penyebaran kuesioner dilakukan secara online menggunakan google form yang disebar melalui grup whatssapp tiap angkatan dengan meminta bantuan kepada guru di sekolah tersebut. Validasi isi kuesioner dilakukan terhadap 6 orang sesuai kriteria responden 
namun tidak termasuk ke dalam sampel. Jumlah sampel yang dibutuhkan adalah sebanyak 63 orang dari total populasi 157 orang dihitung dengan rumus slovin.

Responden memiliki pengetahuan, sikap dan perilaku yang jika pada setiap kategori pertanyaan responden memiliki nilai sebagai berikut:
a)
Baik
: 67-100
b)
Cukup Baik : :33-66
c) Buruk

\section{Hasil dan Pembahasan}

Tabel 1

Data Sebaran Karakteristik Responden

\begin{tabular}{cccc}
\hline \multicolumn{2}{l}{ Karakteristik Responden (n=63) } & & \\
\cline { 1 - 3 } & Jumlah & Persentase (\%) & Mean \\
\hline Usia (tahun) & & 1.6 & \\
\hline 15 & 1 & 34.9 & \\
\hline 16 & 22 & 36.5 & \\
\hline 17 & 23 & 27 & \\
\hline 18 & 17 & & \\
\hline Jenis Kelamin & & 95.2 & \\
\hline Perempuan & 60 & 4.8 & \\
\hline Laki-Laki & 3 & & \\
\hline Kelas & & 33,33 & \\
\hline 10 & 21 & 31,75 & \\
\hline 11 & 20 & 34,92 & \\
\hline 12 & 22 & & \\
\hline
\end{tabular}

Usia responden rata-rata adalah 17 tahun dari rentang usia 15-18 tahun. Responden dengan usia 15 tahun hanya $(1,6 \%)$, usia 16 tahun sebanyak $(34,9 \%)$, usia 17 tahun dengan jumlah terbanyak yaitu (36,5\%) sedangkan usia 18 tahun sebanyak (27\%). Mayoritas responden adalah perempuan $(95,2 \%)$ dan laki-laki $(4,85)$ dari total 63 orang. Sedangkan responden yang menduduki kelas 10 sebanyak $(33,33 \%)$, kelas 11 sebanyak $(31,75 \%)$ dan kelas 12 sebanyak $(34,92 \%)$.

Sinar UV dapat memberikan dampak buruk bagi kulit manusia apabila terpapar terlalu lama (BPOM, 2009). Sebanyak $(95,2 \%)$ responden mengetahui bahwa sinar

\section{Tabel 2}

\section{Gambaran Jawaban Tepat Siswa-Siswi SMK Kesehatan Yanna Husada terhadap Kuesioner Pengetahuan $(n=63)$}

\begin{tabular}{|c|c|c|c|}
\hline No. & Pertanyaan & $\begin{array}{c}\text { Jawaban Tepat } \\
\text { n }(\%)\end{array}$ & $\begin{array}{c}\text { Bobot }= \\
100\end{array}$ \\
\hline
\end{tabular}




\begin{tabular}{llll}
\hline 1. & $\begin{array}{l}\text { Sinar matahari dapat memberikan dampak } \\
\text { buruk terhadap kulit }\end{array}$ & $60(95,2)$ & 3,35 \\
\hline 2. & $\begin{array}{l}\text { Penyebab sinar matahari dapat memberikan } \\
\text { dampak buruk terhadap kulit }\end{array}$ & $2(3,2)$ & 8,66 \\
\hline 3. & $\begin{array}{l}\text { Dampak buruk yang dapat terjadi akibat } \\
\text { paparan sinar matahari }\end{array}$ & $12(19)$ & 10 \\
\hline 4. & Waktu aman untuk terpapar sinar matahari & $33(52,4)$ & 5 \\
\hline 5. & $\begin{array}{l}\text { Terdapat kosmetik yang dapat melindungi } \\
\text { dari sinar matahari }\end{array}$ & $60(95,2)$ & 3,35 \\
\hline 6. & $\begin{array}{l}\text { Kosmetik yang dapat melindungi dari sinar } \\
\text { matahari }\end{array}$ & $60(95,2)$ & 5 \\
\hline 7. & $\begin{array}{l}\text { Waktu seseorang perlu menggunakan } \\
\text { sunscreen }\end{array}$ & $6(9,5)$ & 5 \\
\hline 8. & $\begin{array}{l}\text { Alasan seseorang perlu menggunakan } \\
\text { sunscreen pada jam tertentu }\end{array}$ & $8(12,7)$ & 8,66 \\
\hline 9. & $\begin{array}{l}\text { Hal yang dapat dicegah dari penggunaan } \\
\text { sunscreen yang dilakukan secara teratur }\end{array}$ & $3(4,8)$ & 8,66 \\
\hline 10. & $\begin{array}{l}\text { Manfaat yang dapat diperoleh dari } \\
\text { penggunaan sunscreen }\end{array}$ & $22(34,9)$ & 8,66 \\
\hline 11. & Kepanjangan SPF & $33(52,4)$ & 5 \\
\hline 12. & Nilai minimal SPF yang paling ideal & $40(63,5)$ & 5 \\
\hline 13. & Kepanjangan PA & $43(68,3)$ & 5 \\
\hline 14. & $\begin{array}{l}\text { Jenis warna kulit yang memerlukan } \\
\text { sunscreen }\end{array}$ & $21(33,3)$ & 10 \\
\hline 15. & $\begin{array}{l}\text { Hal yang menyebabkan keefektifan } \\
\text { sunscreen berkurang }\end{array}$ & $3(4,8)$ & 8,66 \\
\hline & $\quad$ & \\
\hline
\end{tabular}

Sebanyak (19\%) responden menjawab dengan tepat dampak buruk yang dapat terjadi terhadap kulit akibat radiasi sinar UV. UVA dapat menyebabkan timbulnya tumor jinak pada kulit maupun kanker kulit. Efek buruk dari radiasi UVB dapat menyebabkan kerusakan DNA baik secara langsung maupun tidak langsung, stress oksidatif, penuaan dini, berbagai efek terhadap sistem imun hingga tumor kulit. Radiasi dari UVC dapat merusak molekul DNA dengan kekuatan yang dapat menembus kulit sampai 60-80 nm (Nichols \& Katiyar, 2010).

Pukul 07.00 pagi merupakan waktu saat intensitas UVB dari sinar matahari berada pada level rendah. Intensitas tersebut semakin meningkat hingga pukul 11.00. Intensitas ini kemudian terus menurun hingga pada pukul 16.00 berada pada level yang sama seperti pukul 07.00 (Setiati, Siti. 2008). Responden yang menjawab dengan tepat pertanyaan mengenai waktu aman untuk kulit terpapar sinar matahari sebanyak $(52,4 \%)$.

Perlindungan kimiawi pada kulit agar terlindung dari sinar matahari yaitu dengan menggunakan produk kosmetika seperti tabir surya atau sunscreen (Dewi \& Neti, 2013; Watson, 2016) Responden mengetahui terdapat kosmetika yang dapat melindungi kulit dari sinar matahari dilihat dari jawaban tepat responden sebanyak $(95,2 \%)$. Responden juga mengetahui kosmetika tersebut adalah sunscreen terlihat pada pertanyaan tersebut responden menjawab dengan tepat sebanyak $(95,2 \%)$.

Kulit perlu dilindungi dengan sunscreen saat intensitas sinar matahari meningkat. Hanya sedikit yang mampu menjawab dengan tepat mengenai waktu seseorang perlu menggunakan sunscreen yaitu sebanyak (9,5\%). Mengenai alasan seseorang perlu menggunakan sunscreen pada jam tersebut tentunya berkaitan dengan 
intesitas sinar matahari. Namun hanya sedikit yang mampu menjawab dengan benar yaitu sebanyak $(12,7 \%)$.

Tabir surya atau sunscreen dapat mencegah atau meminimalisir kulit dari pengaruh buruk sinar matahari baik akut (jangka pendek) maupun kronik atau jangka panjang (Minerva, 2019). hal yang dapat dicegah dari penggunaan sunscreen yang dilakukan secara teratur sedikit sekali responden yang menjawab dengan benar yaitu sebanyak $(4,8 \%)$.

Penggunaan sunscreen dapat memantulkan radiasi sinar UV pada kulit yang sering terpapar sinar UV (Minerva, 2018). Manfaat yang dapat diperoleh dari penggunaan sunscreen terdapat $(34,9 \%)$ responden yang menjawab dengan benar.

SPF (Sun Protection Factor) merupakan tanda kekuatan atau lamanya suatu sunscreen dalam melindungi kulit dari sinar matahari (Minerva, 2019). Pertanyaan mengenai kepanjangan SPF dijawab dengan tepat oleh $(52,4 \%)$ responden.

SPF yang dibutuhkan untuk daerah tropis seperti Indonesia adalah diatas 15 yaitu 30 (Poon \& Barnetson, 2002). pertanyaan mengenai nilai minimal SPF paling ideal adalah sebesar $(63,5 \%)$ responden yang menjawab dengan tepat.

PA adalah singkatan dari Protection Grade of UVA yang merupakan tanda dalam menunjukkan tingkat perlindungan sunscreen terhadap UVA. Semakin banyak tanda (+) di depan PA berarti semakin tinggi pula proteksi sunscreen tersebut terhadap UVA (Ho, 2001). Pertanyaan mengenai kepanjangan PA berhasil dijawab dengan benar sebanyak $(68,3 \%)$ dari seluruh total responden.

Setiap warna kulit memiliki reaksi atau derajat kepekaan yang berbeda terhadap sinar matahari. Hal ini dipengaruhi oleh jumlah melanin dalam kulit. Orang berkulit gelap memiliki jumlah melanin yang lebih banyak dibandingkan orang berkulit putih. Namun bukan berarti orang berkulit gelap tidak mengalami efek buruk dari sinar matahari, hanya saja butuh paparan yang lebih kuat untuk melihat gejalanya (Bambang Noviansyah, 2016; Supriyatno et al., 2010). Dari teori tersebut dapat diketahui semua jenis warna kulit tetap memerlukan sunscreen. Pertanyaan mengenai warna kulit yang memerlukan sunscreen sebanyak $(33,3 \%)$ responden menjawab dengan benar.

Efektivitas sunscreen ditentukan oleh cara pakai, diantaranya adalah jumlah yang cukup, pemakaian yang teratur setiap hari, waktu pemakaian, pemakaia ulang serta kadar (nilai SPF) (Bambang Noviansyah, 2016; Basri, 2014). Terdapat $(4,8 \%)$ responden yang menjawab dengan benar pertanyaan tentang hal yang menyebabkan keefektifan sunscreen berkurang.

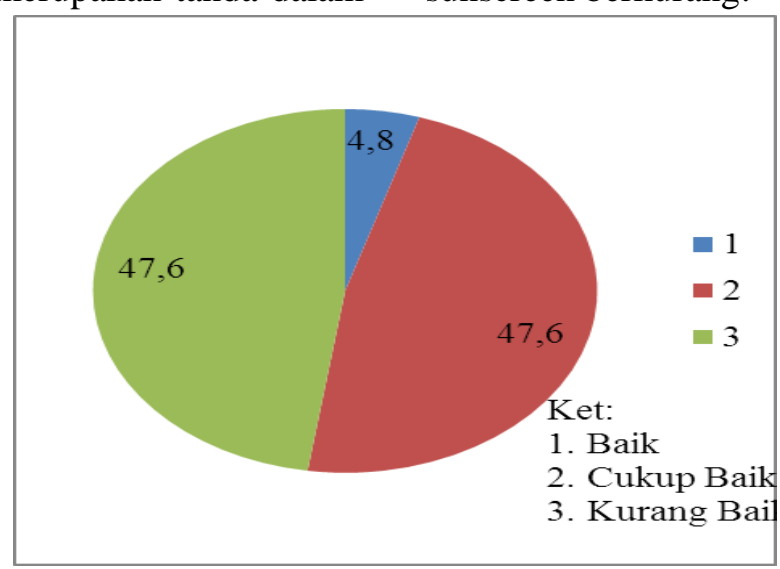

Gambar 1

Gambaran persentase nilai pengetahuan siswa-siswi SMK Kesehatan Yannas Husada 
Sebanyak $(95,2 \%)$ dari total 63 responden menyatakan menggunakan sunscreen merupakan hal yang penting bagi mereka. Hal paling penting dalam memilih sunscreen yang akan dibeli yaitu dengan memperhatikan nomor izin edar, tanggal kadaluwarsa dan nilai SPF. Namun, sikap responden dalam memilih sunscreen yang akan dibeli masih banyak yang kurang atau tidak tepat terlihat dari persentase jawaban tepat hanya berjumlah $(44,4 \%)$.

Tabel 3

Gambaran Jawaban Tepat Siswa-Siswi SMK Kesehatan Yannas Husada terhadap Kuesioner Sikap $(n=63)$

\begin{tabular}{llcc}
\hline No. & \multicolumn{1}{c}{ Pertanyaan } & $\begin{array}{c}\text { Jawaban Tepat } \\
\mathrm{n}(\%)\end{array}$ & Bobot (=100) \\
\hline 1. & $\begin{array}{l}\text { Menggunakan sunscreen merupakan hal yang } \\
\text { penting bagi anda }\end{array}$ & $60(95,2)$ & 7 \\
\hline 2. & $\begin{array}{l}\text { Pertimbangan anda dalam memilih sunscreen } \\
\text { yang akan dibeli }\end{array}$ & $28(44,4)$ & 11 \\
\hline 3. & $\begin{array}{l}\text { Pertimbangan anda dalam memilih sunscreen } \\
\text { berdasarkan nilai SPF }\end{array}$ & $15(23,8)$ & 11 \\
\hline 4. & Nilai SPF yang akan anda pilih & $41(65,1)$ & 8 \\
\hline 5. & $\begin{array}{l}\text { Bagian tubuh yang menurut anda paling perlu } \\
\text { menggunakan sunscreen }\end{array}$ & $8(12,7)$ & 11 \\
\hline 6. & Lama sunscreen dapat terserap ke dalam kulit & $10(15,9)$ & 8 \\
\hline 7. & Pemilihan sunscreen berdasarkan jenis & $41(65)$ & 11 \\
\hline 8. & Alasan menggunakan sunscreen & $17(26,98)$ & 11 \\
\hline 9. & $\begin{array}{l}\text { Cara yang dilakukan untuk melindungi kulit } \\
\text { dari sinar matahari jika tidak ada sunscreen }\end{array}$ & $1(1,5)$ & 11 \\
\hline 10. & $\begin{array}{l}\text { Alasan ketika tidak atau lupa menggunakan } \\
\text { sunscreen }\end{array}$ & $4(6,3)$ & 11 \\
\hline
\end{tabular}

Warna kulit mempengaruhi sensitivitas kulit terhadap sinar matahari karena jumlah melanin yang juga berbeda pada setiap warna kulit (Cahyono \& Widiati, 2015) sehingga warna kulit berpengaruh terhadap pemilihan sunscreen. Pekerja lapangan menerima paparan sinar matahari sebanyak (10\%-70\%) setiap harinya dibandingkan pekerja kantoran yang hanya menerima (6\%) paparan sinar matahari setiap harinya (Astuti \& Pamudji, 2015). Hal ini menandakan jenis aktivitas di luar atau di dalam atau di luar ruangan berpengaruh terhadap pemilihan sunscreen. Sinar matahari di suatu daerah dalam hal ini Indonesia sebagai daerah dengan intensitas paparan sinar matahari yang tinggi sepanjang tahunnya (Rahmawati et al., 2018). Sebanyak $(23,8 \%)$ responden menjawab dengan tepat.

Nilai SPF yang baik adalah di atas 15 (Minerva, 2018). Untuk daerah tropis perlu SPF diatas 15 yaitu 30 serta diperlukan SPF $30+$ agar terhindar dari erithema dan sunburn (Poon \& Barnetson, 2002). Terdapat $(65,1 \%)$ yang menjawab dengan tepat pemilihan SPF 30.

Pemakaian sunscreen tidak terbatas pada area wajah saja, tetapi juga pada bagian tubuh lain yang sering terpapar sinar matahari seperti leher, tangan, lengan, kaki hingga betis atau bagian tubuh lainnya. Namun, hanya $(12,7 \%)$ responden yang menyikapi penggunaan sunscreen perlu pada wajah, leher, tangan dan lengan serta kaki dan betis. 
Waktu pemakaian sunscreen paling baik agar sunscreen dapat optimal terserap ke dalam kulit adalah 15-30 menit sebelum keluar rumah atau terpapar sinar matahari (Minerva, 2018). Sebanyak (15,9\%) responden yang menjawab dengan tepat mengenai lama sunscreen dapat terserap ke dalam kulit.

Sebanyak (65\%) responden memilih sunscreen yang mampu melindungi dari sinar UVA dan UVB terlihat persentase yang dijawab dengan tepat. Sunscreen yang mampu melindungi dari UVA dan UVB merupakan spektrum luas yang memiliki potensi alergi lebih rendah sehingga lebih aman digunakan oleh anak-anak dimana kulit anak-anak lebih sensitif dibandigkan kulit orang dewasa (Minerva, 2019).

Alasan responden menggunakan sunscreen dengan jawaban tepat $(26,98 \%)$. Kebanyakan responden hanya memilih salah satu dari kedua pilihan tepat sehingga diperoleh jawaban tepat dengan persentase yang juga sedikit. Hal ini sesuai dengan penelitian (Tasya Suherman, 2021) menunjukkan responden telah paham akan pentingnya penggunaan sunscreen namun sikap mereka menggunakan sunscreen masih banyak yang kurang tepat.

Responden menjawab pertanyaan dengan tepat yaitu (1,5\%). Sedikit sekali responden yang memilih semua pilihan sehingga diperoleh jawaban tepat yang sedikit pula. Kebanyakan responden memilih menggunakan pakaian lengan panjang atau tertutup jika tidak ada sunscreen. Hal ini sama dengan hasil penelitian yang dilakukan oleh (Tasya Suherman, 2021) bahwa responden lebih memilih memakai pakaian tertutup.

Alasan responden tidak menggunakan sunscreen masih banyak yang tidak tepat dilihat dari persentase jawaban tepat hanya $(6,3 \%)$. Responden tidak memakai sunscreen karena malas dan terburu-buru. Ini bukanlah jawaban tepat, karena dilihat dari hal tersebut berarti responden tahu pentingnya sunscreen namun sikap dalam memakainya masih sangat rendah. Hasil ini sama dengan hasil yang diperoleh pada penelitian yang dilakukan oleh (Tasya Suherman, 2021) bahwa responden telah paham akan pentingnya penggunaan sunscreen namun sikap mereka terhadap penggunaan sunscreen masih rendah.

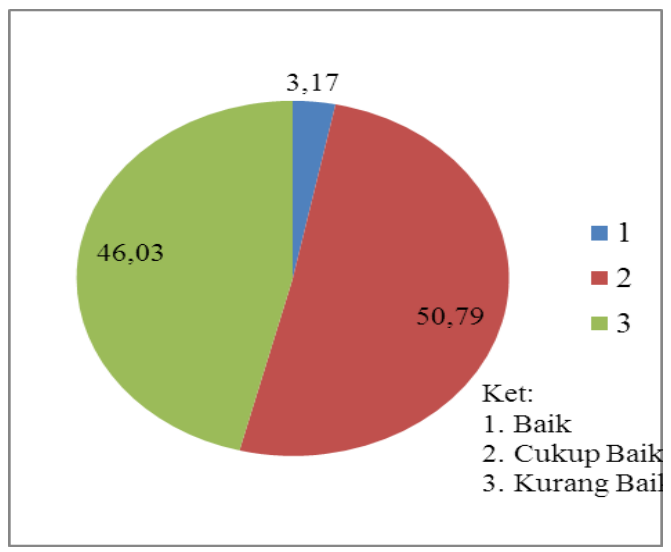

Gambar 2

\section{Gambaran Sikap Siswa-Siswi SMK Kesehatan Yannas Husada}

Untuk mencegah kulit terpapar sinar matahari diperlukan penggunaan sunscreen secara teratur dan dengan jumlah yang cukup (Setyowibowo et al., 2017; Stafford et al.,
2002) Responden menggunakan sunscreen setiap hari secara teratur hanya $(63,5 \%)$

Seperti yang telah diketahui penggunaan sunscreen adalah terhadap 
seluruh bagian tubuh yang terkena sinar matahari. Namun, sedikit sekali atau hanya sebesar $(3,2 \%)$ responden yang menjawab dengan tepat bagian tubuh yang mereka pakaikan sunscreen. Kebanyakan dari responden menggunakan sunscreen hanya pada wajah saja.

Kosmetik yang berfungsi melindungi kulit dari sinar matahari disebut sunscreen
(Tranggono \& Latifah, 2007). Artinya ketika melakukan aktivitas apapun yang membuat kulit terkena sinar matahari hendaknya menggunakan sunscreen sebagai perlindungan kulit. responden yang menjawab dengan tepat bahwa semua aktivitas yang terdapat dalam pilihan merupakan aktivitas yang perlu menggunakan sunscreen hanya $(17,5 \%)$.

\section{Tabel 4}

Gambaran Jawaban Tepat Siswa-Siswi SMK Kesehatan Yannas Husada terhadap Kuesioner Perilaku (n=63)

\section{No. Pertanyaan}

\section{Jawaban Tepat}

n $(\%)$

\begin{tabular}{|c|c|c|c|}
\hline 1. & $\begin{array}{l}\text { Menggunakan sunscreen setiap hari secara } \\
\text { teratur }\end{array}$ & $40(63,5)$ & 8 \\
\hline 2. & $\begin{array}{l}\text { Bagian tubuh yang selalu anda pakaikan } \\
\text { sunscreen }\end{array}$ & $2(3,2)$ & 11,5 \\
\hline 3. & $\begin{array}{l}\text { Aktivitas yang membuat anda menggunakan } \\
\text { sunscreen }\end{array}$ & $11(17,5)$ & 11,5 \\
\hline 4. & $\begin{array}{l}\text { Waktu pemakaian sunscreen yang paling tepat } \\
\text { bagi anda }\end{array}$ & $6(9,5)$ & 10 \\
\hline 5. & Tiap berapa jam penggunakan ulang sunscreen & $9(14,3)$ & 10 \\
\hline 6. & $\begin{array}{l}\text { Hal-hal yang menyebabkan anda lupa atau } \\
\text { sengaja tidak menggunakan ulang sunscreen }\end{array}$ & $10(15,9)$ & 11,5 \\
\hline 7. & $\begin{array}{l}\text { Jumlah pemakaian sunscreen yang anda pakai } \\
\text { untuk wajah dan leher }\end{array}$ & $29(46)$ & 10 \\
\hline 8. & $\begin{array}{l}\text { Anda membeli kembali produk sunscreen jika } \\
\text { sudah habis }\end{array}$ & $1(1,6)$ & 11,5 \\
\hline 9. & $\begin{array}{l}\text { Menggunakan produk make up (seperti bedak) } \\
\text { yang mengandung SPF tetap menggunakan } \\
\text { sunscreen }\end{array}$ & $57(90,5)$ & 8 \\
\hline 10. & $\begin{array}{lcc}\text { Tetap menggunakan sunscreen } & \text { meski } \\
\text { menggunakan produk make up ber SPF } & \end{array}$ & $46(73)$ & 8 \\
\hline
\end{tabular}

Waktu penggunaan sunscreen yang paling tepat adalah 15-30 menit sebelum kulit terpapar sinar matahari atau sebelum keluar rumah (Minerva, 2019). Hanya sebanyak $(9,5 \%)$ responden yang menjawab dengan benar waktu penggunaan sunscreen yang paling tepat.

Penggunaan sunscreen perlu diulang setiap 2 jam sekali setelah beraktivitas (Lim et al., 2009). Namun hanya (14,3\%) 
responden yang melakukan penggunaan ulang sunscreen setiap 2 jam sekali

Jumlah Penggunaan sunscreen jika dihitung dengan pengukuran sendok teh yaitu sebanyak 1 sendok teh $(5 \mathrm{ml})$ (Alexandra \& Sinaga, 2021). Berdasarkan anjuran dokter estetika adalah sebanyak 2 ruas jari untuk wajah dan leher. Sebanyak (46\%) responden yang menjawab dengan benar.

Responden yang menjawab pertanyaan dengan tepat hanya berjumlah $(1,6 \%)$. Kebanyakan responden membeli sunscreen di supermarket atau minimarket padahal semua pilihan pada pertanyaan ini adalah pilihan tepat yang bisa menjadi tempat bagi responden membeli sunscreen.

Responden selalu membeli kembali sunscreen yang biasa mereka pakai jika telah habis. Terlihat sebanyak $(90,5 \%)$ responden menjawab dengan tepat. Menurut (Minerva, 2019) sunscreen yang digunakan pada wajah dibiarkan meyerap terlebih dahulu sebelum menggunakan make up. Artinya meski menggunakan make up tetap perlu menggunakan sunscreen. Sebanyak (73\%) responden tetap memakai sunscreen meski mereka menggunakan produk make up ber SPF.

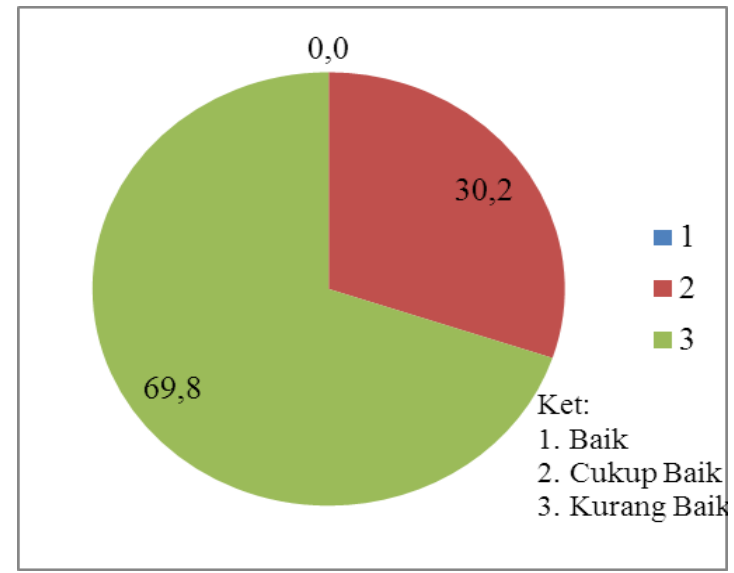

Gambar 3

\section{Gambaran Perilaku Siswa-Siswi SMK Kesehatan Yannas Husada}

Tabel 5

Tabel Uji Chi Square

\begin{tabular}{llc}
\hline No. & \multicolumn{1}{c}{ Variabel } & Nilai $\boldsymbol{P}$ \\
\hline 1. & $\begin{array}{l}\text { Hubungan pengetahuan dan sikap siswa } \\
\text { terhadap penggunaan sunscreen }\end{array}$ & 0,223 \\
\hline 2. & $\begin{array}{l}\text { Hubungan pengetahuan dan perilaku } \\
\text { siswa terhadap penggunaan sunscreen }\end{array}$ & 0,223 \\
\hline 3. & $\begin{array}{l}\text { Hubungan sikap dan perilaku siswa } \\
\text { terhadap penggunaan sunscreen }\end{array}$ & 0,199 \\
\hline
\end{tabular}

Hasil analisis dengan chi square menunjukkan keseluruhan variabel memiliki nilai lebih dari $(0,05)$ sehingga dapat dikatakan tidak ada hubungan diantara hal tersebut. Baik itu hubungan pengetahuan dan sikap, hubungan pengetahuan dan perilaku serta Hubungan sikap dan perilaku siswa terhadap penggunaan sunscreen.

\section{Kesimpulan}

Anak remaja dalam hal ini siswa-siswi SMK Kesehatan Yannas Husada memiliki 
tingkat pengetahuan, sikap dan perilaku yang cukup baik terhadap penggunaan sunscreen.

Sebanyak $(4,8 \%)$ responden memiliki tingkat pengetahuan yang baik terhadap penggunaan sunscreen, sebanyak $(47,6 \%)$ memiliki pengetahuan yang cukup baik dan sisanya sebanyak $(47,6 \%)$ memiliki pengetahuan yang buruk terhadap penggunaan sunscreen.

Sebanyak $(3,17 \%)$ responden memiliki sikap yang baik terhadap penggunaann sunscreen, sebanyak $(50,79 \%)$ memiliki sikap yang cukup baik dan sebanyak (46,03\%) memiliki sikap yang buruk terhadap penggunaan sunscreen.

Sebanyak $(0 \%)$ responden memiliki perilaku yang baik terhadap penggunaann sunscreen, sebanyak $(30,2 \%)$ memiliki perilaku yang cukup baik dan sebanyak $(69,8 \%)$ memiliki perilaku yang buruk terhadap penggunaan sunscreen.

Tidak ada hubungan diantara pengetahuan-sikap, pengetahuan-perilaku serta sikap-perilaku yang dianalisis secara chi square.

\section{BIBLIOGRAFI}

Alexandra, J., \& Sinaga, K. P. (2021). Machine Learning Approaches For Marketing Campaign In Portuguese Banks. 2021 3rd International Conference On Cybernetics And Intelligent System (ICORIS), 1-6. Google Scholar

Astuti, P., \& Pamudji, S. (2015). Analisis Pengaruh Opini Going Concern,Likuiditas,Solvabilitas,Arus Kas, Umur Perusahaan Dan Ukuran Perusahaan Terhadap Kemungkinan Financial Distress. Diponegoro Journal Of Accounting, O(0), 142-152. Google Scholar

Bambang Noviansyah. (2016). Perlindungan Hukum Bagi Konsumen Jasa Bengkel Motor Resmi Di Kota Pangkalpinang. Universitas Bangka Belitung. Google Scholar
Basri, N. R. (2014). Hubungan Gula Darah Sewaktu Dengan Kejadian Fluor Albus Pada Wanita Hamil Usia 13-40 Minggu Di RS Prikasih Pondok Labu Periode Januari-April 2014. Google Scholar

BPOM, R. I. (2009). Pangan Jajanan Anak Sekolah. Badan Pengawas Obat Dan Makanan, Jakarta. Google Scholar

Cahyono, B. Y., \& Widiati, U. (2015). The Teaching Of EFL Vocabulary In The Indonesian Context: The State Of The Art. TEFLIN Journal, 19(1), 1-17. Google Scholar

Dewi, M., \& Neti, S. (2013). AZ Tentang Kosmetik. Jakarta: PT Elex Media Komputindo. Google Scholar

Droge, W. (2002). Free Radicals In The Physiological Control Of Cell Function. Physiological Reviews, 82(1), 47-95. Google Scholar

Hari, P., Nikinmaa, E., Pohja, T., Siivola, E., Bäck, J., Vesala, T., \& Kulmala, M. (2013). Station For Measuring Ecosystem-Atmosphere Relations: SMEAR. In Physical And Physiological Forest Ecology (Pp. 471-487). Springer. Google Scholar

Isfardiyana, S. H. (2014). Pentingnya Melindungi Kulit Dari Sinar Ultraviolet Dancara Melindungikulit Dengan Sunblock Buatan Sendiri. Asian Journal Of Innovation And Entrepreneurship, 3(2), 126-133. Google Scholar

Kockler, J., Oelgemöller, M., Robertson, S., \& Glass, B. D. (2012). Photostability Of Sunscreens. Journal Of Photochemistry And Photobiology C: Photochemistry Reviews, 13(1), 91-110. Google Scholar

Lewies, A., Van Dyk, E., Wentzel, J. F., \& Pretorius, P. J. (2014). Using A Medium-Throughput Comet Assay To Evaluate The Global DNA Methylation Status Of Single Cells. Frontiers In Genetics, 5, 215. Google Scholar 
Pengetahuan Sikap dan Perilaku Anak Remaja Usia 15-18 Tahun terhadap Penggunaan Sunscreen di SMK Kesehatan Yannas Husada Bangkalan

Lim, W. S., Baudouin, S. V, George, R. C., Hill, A. T., Jamieson, C., Le Jeune, I., Macfarlane, J. T., Read, R. C., Roberts, H. J., \& Levy, M. L. (2009). BTS Guidelines For The Management Of Community Acquired Pneumonia In Adults: Update 2009. Thorax, 64(Suppl 3), Iii1-Iii55. Google Scholar

Minerva, P. (2018). Hiperpigmentasi. Google Scholar

Minerva, P. (2019). Masker Tradisional Brokoli Untuk Perawatan Kulit Wajah Kering. Jurnal Kapita Selekta Geografi, 2(8), 118-130. Google Scholar

Nichols, J. A., \& Katiyar, S. K. (2010). Skin Photoprotection By Natural Polyphenols: Anti-Inflammatory, Antioxidant And DNA Repair Mechanisms. Archives of Dermatological Research, 302(2), 7183. Google Scholar

Poon, T. S. C., \& Barnetson, R. S. (2002). The Importance Of Using Broad Spectrum SPF 30+ Sunscreens In Tropical And Subtropical Climates. Photodermatology, Photoimmunology \& Photomedicine, 18(4), 175-178. Google Scholar

Rahmawati, R., Muflihunna, A., \& Amalia, M. (2018). Analisis Aktivitas Perlindungan Sinar Uv Sari Buah Sirsak (Annona Muricata L.) Berdasarkan Nilai Sun Protection Factor (SPF) Secara Spektrofotometri UV-VIS. Jurnal Fitofarmaka Indonesia, 5(2), 284-288. Google Scholar

Setiati, S. (2008). Pengaruh Pajanan Sinar Ultraviolet B Bersumber Dari Sinar Matahari Terhadap Konsentrasi Vitamin D $(25(\mathrm{OH})$ D) Dan Hormon Paratiroit Pada Perempuan Usia Lanjut Indonesia. Kesmas: Jurnal Kesehatan Masyarakat Nasional (National Public Health Journal), 2(4), 147-153. Google Scholar
Setyowibowo, H., Sijbrandij, M., Iskandarsyah, A., Hunfeld, J. A. M., Sadarjoen, S. S., Badudu, D. F., Suardi, D. R., \& Passchier, J. (2017). A Protocol For A Cluster-Randomized Controlled Trial Of A Self-Help PsychoEducation Programme To Reduce Diagnosis Delay In Women With Breast Cancer Symptoms In Indonesia. BMC Cancer, 17(1), 1-8. Google Scholar

Stafford, L. J., Xia, C., Ma, W., Cai, Y., \& Liu, M. (2002). Identification And Characterization Of Mouse MetastasisSuppressor Kiss1 And Its G-ProteinCoupled Receptor. Cancer Research, 62(19), 5399-5404. Google Scholar

Supriyatno, B., Said, M., Hermani, B., Sjarif, D. R., \& Sastroasmoro, S. (2010). Risk Factors Of Obstructive Sleep Apnea Syndrome In Obese Early Adolescents: A Prediction Model Using Scoring System. Paediatric Respiratory Reviews, 11(1), 1. Google Scholar

Tahir, I., \& Jumina, Y. I. (2002). Analisis Aktivitas Perlindungan Sinar UV Secara In Vitro Dan In Vivo Dari Beberapa Senyawa Ester Sinamat Produk Reaksi Kondensasi Benzaldehida Tersubstitusi Dan Alkil Asetat. Makalah Pada Seminar Nasional Kimia XI. Yogyakarta. Jurusan Kimia FMIPA UGM. Google Scholar

Tasya Suherman, R. (2021). Tingkat Keterlibatan Mahasiswa Universitas Multimedia Nusantara Dalam Pembelajaran Daring. Universitas Multimedia Nusantara. Google Scholar

Tranggono, R. I., \& Latifah, F. (2007). Buku Pegangan Ilmu Pengetahuan Kosmetik. Jakarta: PT. Gramedia Pustaka Utama, 3(47), 58-59. Google Scholar

Watson, G. (2016). Responsibility And The Limits Of Evil: Variations On A Strawsonian Theme. In Free Will And Reactive Attitudes (Pp. 127-154). Routledge. Google Scholar 
Safinatul Hujjah, Selma Siahaan

Yaar, M. (1995). Biochemical And Molecular

Changes In Photoaged Skin.

Photodamage. Google Scholar

\section{Copyright holder:}

Safinatul Hujjah, Selma Siahaan (2022)

First publication right:

Jurnal Health Sains

This article is licensed under:

(c) () () 